\begin{abstract}
INTRODUCTION: The aerial parts of the plant Calotropis procera produce milky white latex that causes inflammation of the skin and mucous membranes. Prostaglandins are one of the mediators released in an inflammatory response following induction of cyclooxygenase (COX). In the present study, we have evaluated the role of prostaglandins in inflammatory response elicited by the latex of $C$. procera. Methods: Aqueous extract of dried latex of $C$. procera was injected into the 6-day air-pouch in the rat. The inflammatory response was evaluated by studying the air-pouch fluid for its volume, protein and prostaglandin (PG) $\mathbf{E}_{2}$ concentrations, and leucocyte counts. The granulation tissue from the pouch was quantified and studied for COX-2 expression by reverse transcriptase-polymerase chain reaction. The inhibitory effect of celecoxib and dexamethasone was evaluated on the aforementioned parameters.

Results: Dried latex produced an inflammatory response that was maximum at $6 \mathrm{~h}$. It was associated with the accumulation of protein-rich fluid, leucocytes and $\mathrm{PGE}_{2}$ production. It also resulted in granulation of the pouch cavity that was a maximum on day 3. COX-2 expression could be detected in the granulation tissue on day 1 and it increased progressively up to day 5 . The anti-inflammatory drugs celecoxib and dexamethasone significantly attenuated the inflammatory response and inhibited COX-2 expression in granulation tissue.

Conclusions: Latex of $C$. procera induces an inflammatory response characterized by an early exudative phase accompanied by $\mathrm{PGE}_{2}$ production and a late proliferative phase associated with COX-2 induction. Both the phases were effectively inhibited by COX-2 inhibitors.
\end{abstract}

Key words: Latex, Calotropis procera, Inflammation, Anti-inflammatory drugs, Cyclooxygenase-2

\section{Involvement of prostaglandins in inflammation induced by latex of Calotropis procera}

\author{
Vijay L. Kumar ${ }^{\mathrm{CA}}$ and Yatin M. Shivkar
}

Department of Pharmacology, All India Institute of Medical Sciences, Ansari Nagar, New Delhi 110 029, India

\author{
${ }^{\mathrm{CA}}$ Corresponding author \\ Tel: +911126593681 \\ Fax: +91 1126588663 \\ E-mail: kumarv198@hotmail.com
}

\section{Introduction}

The irritant and pro-inflammatory property of latex of Calotropis procera, a wild-growing plant, has been well established. The milky white latex of this plant irritates the mucous membranes and produces inflammatory reaction on local application or accidental exposure. ${ }^{1,2}$ It also produces acute as well as chronic inflammation in various animal models. The inflammatory property of latex has been attributed to the release of histamine from mast cells and the presence of histamine in the latex itself. ${ }^{3}$ As a result, the latex-induced inflammation could be effectively inhibited by antihistaminic drugs. ${ }^{3,4}$ Like other inflammagens, the latex-induced pleurisy involves fluid exudation and cellular infiltration associated with prostaglandin (PG) production. ${ }^{5}$ The role of $\mathrm{PGE}_{2}$ in latex-induced inflammation is corroborated by its inhibition with classical anti-inflammatory drugs (i.e., non-steroidal anti-inflammatory drugs (NSAIDs)) and glucocorticoids. Both NSAIDs and glucocorticoids inhibit the enzyme cyclooxygenase (COX) that exists as two isoforms, COX-1 and COX-2. COX-1 is constitutive and involved in the physiological production of PGs for normal homeostasis. ${ }^{6} \mathrm{COX}-2$, on the other hand, is cytokine inducible and is expressed at chronic and proliferative inflammatory sites. $^{7}$

The air-pouch model in rodents has been extensively used to study the inflammatory granulomatous reaction characterized by a marked production of biochemical mediators in the fluid exudate as well as an influx of polymorphonuclear leucocyte (PMN) cells and macrophages. ${ }^{8}$ PGs are one of the mediators that could be detected in the air-pouch fluid following injection of an inflammagen primarily by the induction of COX-2.? In the present study we have characterized the latex-induced inflammation in the 
rat air-pouch model and evaluated the role of COX-2 using pharmacological reagents. We have also studied the induction of COX-2 mRNA expression by dried latex (DL) in the granulation tissue by reverse transcriptase-polymerase chain reaction (RT-PCR) and evaluated the effect of celecoxib and dexamethasone.

\section{Materials and methods}

\section{Plant material and drugs}

The latex of $C$. procera was collected from the aerial parts of the plant and dried under shade (DL). It was triturated in normal saline (NS) and centrifuged to obtain a clear solution. The plant was identified by the Raw Materials, Herbarium and Museum Division, National Institute of Science Communication, New Delhi, where a voucher specimen is preserved (Voucher No. PID 1739). The drugs used in this study were obtained from Alembic Ltd (Baroda, Gujarat, India) (Celecoxib) and Wyeth Laboratories Ltd (Mumbai, Maharashtra, India) (Dexamethasone).

\section{Animals}

The study was carried out on male Wistar rats weighing 150-180 g. They were kept at ambient temperature and had free access to water and diet. All experimental procedures described were carried out in accordance with the guidelines of Institutional Animal Ethics Committee.

\section{Induction of air-pouch inflammation by DL}

The air-pouch was produced by subcutaneous injection of $20 \mathrm{ml}$ of air into the dorsum of rats, in the intrascapular area. An additional $10 \mathrm{ml}$ of air was injected into the cavity every third day to maintain the patency of the pouch. ${ }^{10}$ On the seventh day, $1 \mathrm{ml}$ of $1 \%$ solution of DL was injected directly into the pouch to produce an inflammatory response. The animals were sacrificed with an overdose of ether at $2 \mathrm{~h}, 6 \mathrm{~h}, 1$ day, 3 days and 5 days after the injection of DL. The cavity was opened, rinsed with $1 \mathrm{ml}$ of cold saline containing $0.1 \%$ ethylenediamine tetraacetic acid, the fluid collected and the volume of exudate, leucocyte counts and protein concentration measured. An aliquot of exudate was stored at $-20^{\circ} \mathrm{C}$ for measurement of $\mathrm{PGE}_{2}$ concentrations. The granulation tissue from the cavity was carefully dissected out, cleared of adjacent tissues, weighed and stored at $-80^{\circ} \mathrm{C}$ for analysis of COX-2 expression. Celecoxib ( 3 and $30 \mathrm{mg} / \mathrm{kg}$ ) and dexamethasone (0.3 and $10 \mathrm{mg} / \mathrm{kg}$ ) were administered orally as a suspension with 5\% gum acacia in NS, given daily for 3 days, starting $1 \mathrm{~h}$ before the DL injection. The effect of anti- inflammatory drugs was evaluated on the exudate volume, protein concentration, $\mathrm{PGE}_{2}$ concentration and cells at $6 \mathrm{~h}$ after the DL injection, while the effect on granulation tissue weight and COX-2 expression was evaluated on day 3 .

\section{Leucocyte count and measurement of total protein and $\mathrm{PGE}_{2}$ in air pouch fluid}

The air-pouch fluid was diluted with Türks solution, and leucocytes were counted in a Neubauer's chamber under a light microscope (TLC). Smears of airpouch fluid were stained with Giemsa stain, and a differential count of 200 cells for PMN and mononuclear cells was performed. The fluid collected from the air pouch cavity was centrifuged (1000 r.p.m.) for $10 \mathrm{~min}$ and the protein concentration in the supernatant was measured. ${ }^{11}$ The $\mathrm{PGE}_{2}$ concentration was measured in the cell-free exudate by enzyme-linked immunosorbent assay (R\&D Systems).

\section{Analysis of COX-2 expression by RT-PCR}

Total RNA was isolated from the granulation tissue by the acid guanidinium thiocyanate/phenol/chloroform extraction method as described by Chomczynski and Sacchi, ${ }^{12}$ and reverse-transcribed using AMV-reverse transcriptase. The reaction mixture containing $10 \mu \mathrm{g}$ of total RNA, $0.5 \mu \mathrm{g}$ of oligo(dT) 15 , $40 \mathrm{U}$ of RNasin, $10 \mathrm{U}$ of AMV-reverse transcriptase in $1 \times \mathrm{RT}$ buffer was incubated at $37^{\circ} \mathrm{C}$ for $75 \mathrm{~min}$. The reaction was terminated by heating at $90^{\circ} \mathrm{C}$ for $5 \mathrm{~min}$, after which the reaction mixture was stored at $-20^{\circ} \mathrm{C}$. The reverse-transcribed cDNA $(2 \mu \mathrm{l})$ was amplified in a final volume of $25 \mu \mathrm{l}$ containing $1 \times$ PCR buffer, 10 pmol of each of sense and antisense primer, $0.5 \mu \mathrm{l}$ of $1.25 \mathrm{mM} \mathrm{dNTP}$, and $1 \mathrm{U}$ of Taq polymerase, using a thermal cycler. The sequences of the sense and antisense primers were 5'-GGT GTG AAA GGA AAT AAG GAA C-3' and 5'-GAA GGA TGG AGT TGT TGT AGA G-3' for COX $-2 .{ }^{13}$ The sense and antisense primers of $\beta$-actin used as internal control were 5'-CGA CGA GGC CCA GAG CAA GC-3' and 5'-CCA GGG CGA CGT AGC ACA GC- $3^{\prime}$, respectively. ${ }^{14}$ These primer sets yield PCR products of 753 and 498 base pairs for COX-2 and $\beta$-actin, respectively. The amplification conditions were: $\mathrm{COX}-2,94^{\circ} \mathrm{C}$ for $5 \mathrm{~min}$ for one cycle, $94^{\circ} \mathrm{C}$ for $1 \mathrm{~min}$ (denaturation), and $57^{\circ} \mathrm{C}$ for $1 \mathrm{~min}$ (annealing), $72^{\circ} \mathrm{C}$ for $1 \mathrm{~min}$ (extension) for 40 cycles, finally followed by one cycle of $72^{\circ} \mathrm{C}$ for $10 \mathrm{~min}$; $\beta$ actin, $94^{\circ} \mathrm{C}$ for $5 \mathrm{~min}$ for one cycle, $94^{\circ} \mathrm{C}$ for $1 \mathrm{~min}$ (denaturation), and $68^{\circ} \mathrm{C}$ for 1 min (annealing), $72^{\circ} \mathrm{C}$ for $1 \mathrm{~min}$ (extension) for 34 cycles, finally followed by one cycle of $72^{\circ} \mathrm{C}$ for $10 \mathrm{~min}$. The products of PCR reactions were analyzed by agarose (1.2\%) gel electrophoresis. 


\section{Statistical analysis}

Values are expressed as mean \pm standard error of the mean of six observations. Student's $t$-test was used to compare the groups and $p \leq 0.05$ was considered significant.

\section{Results}

\section{Time course of DL-induced inflammatory response in the air-pouch}

DL, when injected into a 6-day air-pouch, led to the formation of granulation tissue and fluid accumulation. The weight of granulation tissue increased from $1.19 \pm 0.01 \mathrm{~g}$ at $2 \mathrm{~h}$ to its maximum on day 3 $(1.51 \pm 0.07 \mathrm{~g})$, and thereafter it declined to $0.97 \pm$ $0.05 \mathrm{~g}$ on day 5 (Fig. 1A). There was a decline in the fluid volume recovered from the air-pouch up to day 3 . The volume of fluid recovered at $2 \mathrm{~h}$ was $1.31 \pm$ $0.12 \mathrm{ml}$ and on day 3 was $0.81 \pm 0.02 \mathrm{ml}$, and it increased to $0.97 \pm 0.02 \mathrm{ml}$ on day 5 . The protein concentration of the exudate was maximum at $6 \mathrm{~h}$ $(19.68 \pm 0.98 \mathrm{mg} / \mathrm{ml})$ and this was followed by a rapid decline to $6.40 \pm 0.48 \mathrm{mg} / \mathrm{ml}$ within $24 \mathrm{~h}$, and thereafter a constant decline to $4.00 \pm 0.43 \mathrm{mg} / \mathrm{ml}$ on day 5 (Fig. 1B). Injection of DL into the air-pouch also led to cellular influx, which mainly involved the PMN cells. The PMN count at $6 \mathrm{~h}$ was $36.94 \pm 1.16 \times 10^{6} / \mathrm{ml}$ against $0.10 \pm 0.05 \times 10^{6} / \mathrm{ml}$ at $2 \mathrm{~h}$. This was followed by a marginal increase in monocytes from
$4.00 \pm 0.53 \times 10^{6} / \mathrm{ml}$ at $6 \mathrm{~h}$ to $10.27 \pm 1.41 \times 10^{6} / \mathrm{ml}$ on day 1 , followed by a decline (Fig. 1C). Figure 1D shows the levels of PGs in the fluid recovered from the air-pouch. A significant increase in $\mathrm{PGE}_{2}$ concentration was observed at $6 \mathrm{~h}$ where the concentration of $\mathrm{PGE}_{2}$ was $8.25 \pm 0.28 \mathrm{ng} / \mathrm{ml}$.

\section{Effect of anti-inflammatory drugs on DL-induced air-pouch inflammation}

The anti-inflammatory drugs celecoxib and dexamethasone when administered $1 \mathrm{~h}$ before injecting DL into the air-pouch produced a significant decrease in the inflammatory response in a dose-dependent manner (Table 1). Both, celecoxib $(30 \mathrm{mg} / \mathrm{kg})$ and dexamethasone $(10 \mathrm{mg} / \mathrm{kg})$ decreased the fluid volume from $1.18 \pm 0.02 \mathrm{ml}$ to $0.62 \pm 0.07 \mathrm{ml}$ and $0.72 \pm$ $0.06 \mathrm{ml}$, respectively. Dexamethasone was more potent than celecoxib in reducing the protein concentration of the fluid recovered from the air-pouch and brought down the protein concentration from 19.68 \pm $0.98 \mathrm{mg} / \mathrm{ml}$ to $3.40 \pm 0.3 \mathrm{mg} / \mathrm{ml}$ ( $83 \%$ reduction). The protein concentration of the fluid recovered from celecoxib $(3 \mathrm{mg} / \mathrm{kg}$ ) treated group was $11.70 \pm 0.95$ $\mathrm{mg} / \mathrm{ml}$ (41\% reduction). Cellular infiltration into the air-pouch was also significantly inhibited by celecoxib and dexamethasone. The TLC decreased from $41.08 \pm$ $0.92 \times 10^{6} / \mathrm{ml}$ to $19.4 \pm 1.80 \times 10^{6} / \mathrm{ml}$ and $9.93 \pm$ $1.09 \times 10^{6} / \mathrm{ml}$ with $3 \mathrm{mg} / \mathrm{kg}$ and $30 \mathrm{mg} / \mathrm{kg}$ doses of celecoxib, respectively. Dexamethasone treatment on the other hand brought down the TLC to
A
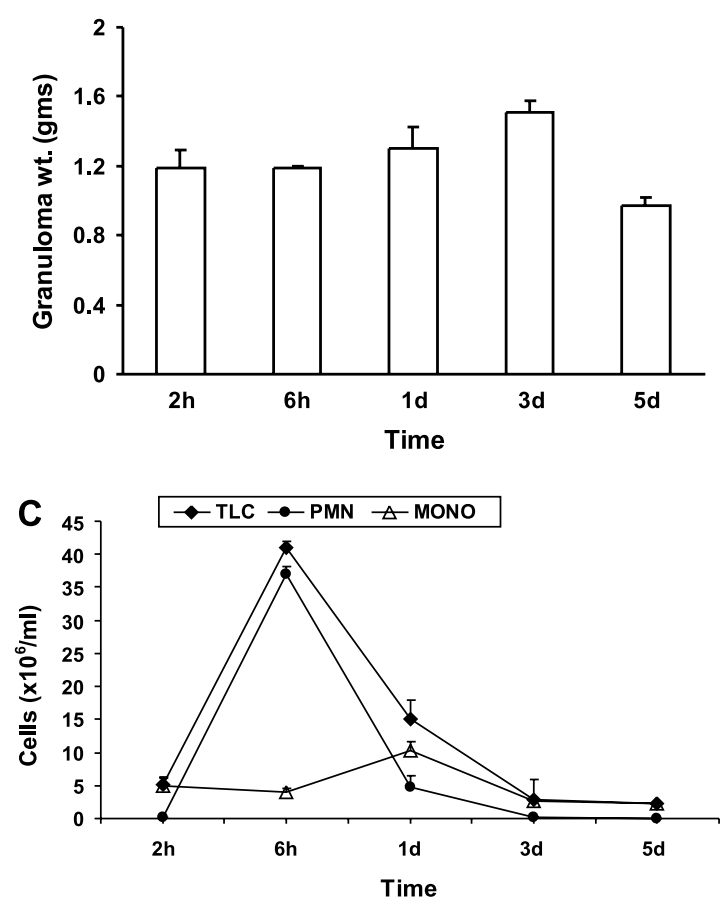

B

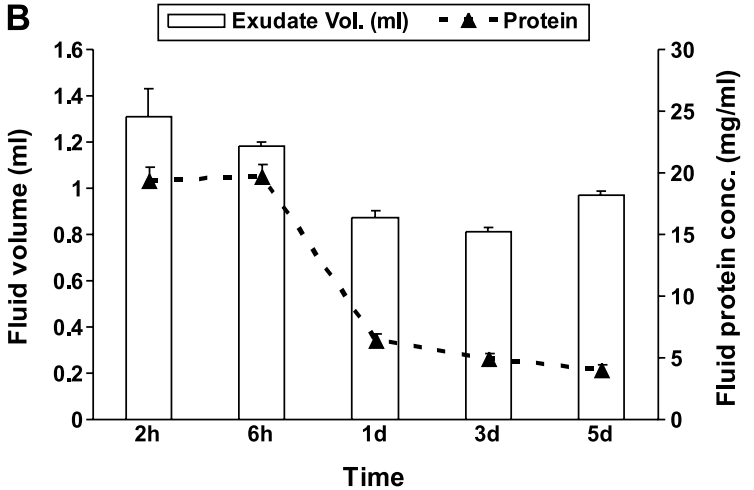

D

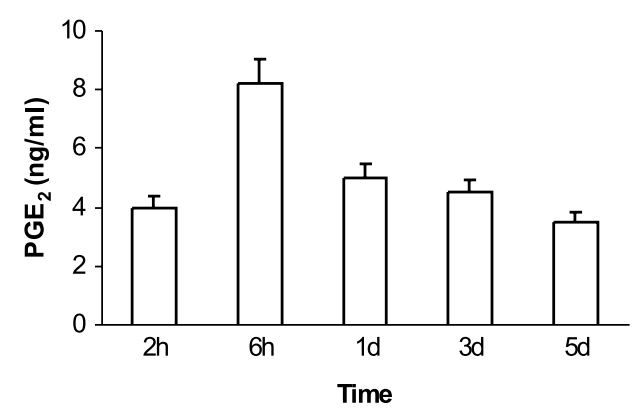

FIG. 1. Time course of granulation tissue formation (A), fluid exudation (B), cellular infiltration (C) and PGE ${ }_{2}$ concentration (D) in the rat air-pouch after injection of $10 \mathrm{mg} \mathrm{DL}$. Results are expressed as mean \pm standard error of the mean. 
Table 1. Anti-inflammatory effect of drugs administered orally $1 \mathrm{~h}$ before injecting $\mathrm{DL}$ into the air-pouch cavity

\begin{tabular}{|c|c|c|c|c|c|}
\hline & Control & $\begin{array}{l}\text { Celecoxib } \\
(3 \mathrm{mg} / \mathrm{kg})\end{array}$ & $\begin{array}{l}\text { Celecoxib } \\
(30 \mathrm{mg} / \mathrm{kg})\end{array}$ & $\begin{array}{l}\text { Dexamethasone } \\
(0.3 \mathrm{mg} / \mathrm{kg})\end{array}$ & $\begin{array}{l}\text { Dexamethasone } \\
\quad(10 \mathrm{mg} / \mathrm{kg})\end{array}$ \\
\hline Exudate volume (ml) & $1.18 \pm 0.02$ & $0.95 \pm 0.03^{\mathrm{b}}(19 \%)$ & $0.62 \pm 0.07^{\mathrm{b}}(47 \%)$ & $0.93 \pm 0.02^{\mathrm{b}}(21 \%)$ & $0.72 \pm 0.06^{\mathrm{b}}(39 \%)$ \\
\hline $\begin{array}{l}\text { Protein concentration } \\
(\mathrm{mg} / \mathrm{ml})\end{array}$ & $19.68 \pm 0.98$ & $14.90 \pm 0.75^{\mathrm{b}}(24 \%)$ & $11.70 \pm 0.95^{\mathrm{b}}(41 \%)$ & $12.00 \pm 1.02^{b}(39 \%)$ & $3.40 \pm 0.30^{\mathrm{b}}(83 \%)$ \\
\hline $\operatorname{TLC}\left(\times 10^{6} / \mathrm{ml}\right)$ & $41.08 \pm 0.92$ & $19.40 \pm 1.80^{\mathrm{b}}(53 \%)$ & $9.93 \pm 1.09^{b}(76 \%)$ & $9.80 \pm 1.65^{b}(76 \%)$ & $4.53 \pm 1.05^{\mathrm{b}}(89 \%)$ \\
\hline PMN $\left(\times 10^{6} / \mathrm{ml}\right)$ & $36.94 \pm 1.16$ & $6.87 \pm 1.94^{\mathrm{b}}(81 \%)$ & $0.30 \pm 0.22^{\mathrm{b}}(99 \%)$ & $1.61 \pm 0.56^{\mathrm{b}}(96 \%)$ & $0.30 \pm 0.10^{\mathrm{b}}(99 \%)$ \\
\hline Monocytes $\left(\times 10^{6} / \mathrm{ml}\right)$ & $4.00 \pm 0.53$ & $12.57 \pm 0.73^{\mathrm{b}}(214 \%)$ & $9.64 \pm 0.91^{\mathrm{b}}(141 \%)$ & $8.19 \pm 1.17^{\mathrm{a}}(105 \%)$ & $4.23 \pm 1.16(6 \%)$ \\
\hline $\mathrm{PGE}_{2}(\mathrm{ng} / \mathrm{ml})$ & $8.25+0.28$ & $2.00+0.12^{\mathrm{b}}(76 \%)$ & $1.60+0.14^{\mathrm{b}}(81 \%)$ & $0(100 \%)$ & $0(100 \%)$ \\
\hline Granuloma weight $(\mathrm{g})$ & $1.51 \pm 0.07$ & $1.19 \pm 0.02^{\mathrm{a}}(21 \%)$ & $0.74 \pm 0.11^{\mathrm{b}}(51 \%)$ & $0.58 \pm 0.06^{\mathrm{b}}(62 \%)$ & $0.28 \pm 0.04^{\mathrm{b}}(81 \%)$ \\
\hline
\end{tabular}

Values presented as mean \pm standard error of the mean $(n=6)$. Values in brackets represent the percentage change as compared with the respective control.

${ }^{\mathrm{a}} p \leq 0.05$. ${ }^{\mathrm{b}} p \leq 0.001$

$9.80 \pm 1.65 \times 10^{6} / \mathrm{ml}$ and $4.53 \pm 1.05 \times 10^{6} / \mathrm{ml}$ at 0.3 $\mathrm{mg} / \mathrm{kg}$ and $10 \mathrm{mg} / \mathrm{kg}$ doses, respectively. A similar pattern was also obtained in case of the PMN count, where both celecoxib $(30 \mathrm{mg} / \mathrm{kg})$ and dexamethasone (10 $\mathrm{mg} / \mathrm{kg}$ ) produced 99\% inhibition of PMN influx. The monocyte count, on the other hand, showed an increase at low doses of celecoxib $(3 \mathrm{mg} / \mathrm{kg})$ and dexamethasone $(0.3 \mathrm{mg} / \mathrm{kg})$ from $4.00 \pm 0.53 \times 10^{6} / \mathrm{ml}$ to $12.53 \pm 0.73 \times 10^{6} / \mathrm{ml}$ and $8.19 \pm 1.17 \times 10^{6} / \mathrm{ml}$, respectively. At higher doses of celecoxib $(30 \mathrm{mg} / \mathrm{kg}$ ) and dexamethasone $(10 \mathrm{mg} / \mathrm{kg})$, the monocyte count was $9.64 \pm 0.91 \times 10^{6} / \mathrm{ml}$ and $4.23 \pm 1.16 \times 10^{6} / \mathrm{ml}$. Both these drugs significantly decreased the $\mathrm{PGE}_{2}$ concentration of the fluid. $\mathrm{PGE}_{2}$ could not be detected in animals treated with dexamethasone (100\% inhibition) while $76-81 \%$ inhibition of $\mathrm{PGE}_{2}$ production was obtained with celecoxib. Both celecoxib and dexamethasone also inhibited the formation of granulation tissue. The weight of granulation tissue in celecoxib $(3 \mathrm{mg} / \mathrm{kg}$ and $30 \mathrm{mg} / \mathrm{kg}$ ) treated groups was $1.19 \pm 0.02$ $\mathrm{g}$ and $0.74 \pm 0.11 \mathrm{~g}$, as against $1.51 \pm 0.07 \mathrm{~g}$ in control group. The weight of the granulation tissue was $0.58 \pm$ $0.06 \mathrm{~g}$ and $0.28 \pm 0.04 \mathrm{~g}$ in dexamethasone $(0.3 \mathrm{mg} / \mathrm{kg}$ and $10 \mathrm{mg} / \mathrm{kg}$ ) treated groups.

\section{Inhibitory effect of anti-inflammatory drugs on COX-2 expression in air-pouch granulation tissue}

COX-2 expression was studied in the air-pouch granulation tissue following the administration of DL. COX-2 expression was induced by DL and a 753 base pair COX-2 fragment was generated following RT-PCR by the primers used in this study. The COX-2 expression could be detected on day 1 of induction and the intensity of the band progressively increased up to day 5 (Fig. 2A). Since the weight of granulation tissue was maximum on day 3 , the effect of celecoxib and dexamethasone on COX-2 expression was evaluated on day 3. Treatment of the rats with celecoxib and dexamethasone completely inhibited COX-2 expression even at the lower doses (Fig. 2B).

\section{Discussion}

The irritant and pro-inflammatory properties of the latex of $C$. procera have been well established in different inflammatory models. One of the mediators involved in the inflammatory response elicited by DL has been identified as histamine. ${ }^{3}$ Besides histamine, there are various other mediators that contribute to the inflammatory response. Of these, PGs play a crucial role in inflammatory cell influx, neovascularization and cellular proliferation. ${ }^{15}$ Since COX-2 is a key enzyme in the formation of PGs, the present study was carried out to evaluate the effect of DL on COX-2 induction. Single injection of DL into the airpouch produced a characteristic inflammatory response that included fluid exudation, leucocyte infiltration and tissue granulation. Fluid exudation and the increase in protein concentration of the fluid has been attributed to increased capillary permeability. ${ }^{4}$ The exudation of plasma protein in the pouch was followed by an influx of leucocytes as also reported for other inflammagens. ${ }^{16}$ Polymorphonuclear cells are the predominant cell type in the early phase of inflammation and thereafter these cells are replaced by migrating mononuclear cells. ${ }^{17}$ The inflammation induced by DL was significantly inhibited by celecoxib (a COX-2 inhibitor) and

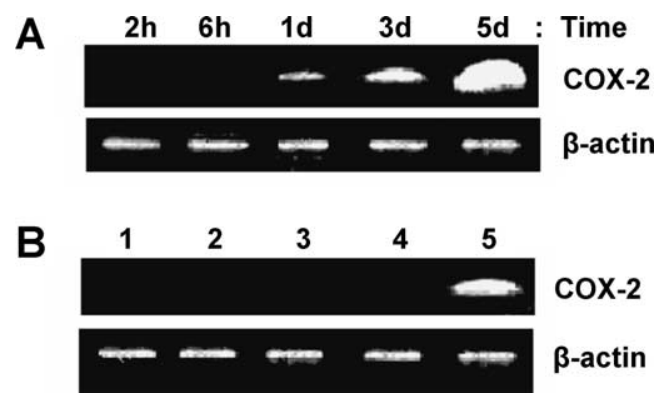

FIG. 2. RT-PCR results of COX-2 mRNA expression in rat airpouch granulation tissue. $\beta$-Actin was used as internal control. (A) Temporal changes in COX-2 expression from day 1 to day 5 . (B) Inhibition of COX-2 expression in day 3 granulation tissue after treatment with $3 \mathrm{mg} / \mathrm{kg}$ and $30 \mathrm{mg} / \mathrm{kg}$ of celecoxib (lanes 1 and 2) and $0.3 \mathrm{mg} / \mathrm{kg}$ and $10 \mathrm{mg} / \mathrm{kg}$ of dexamethasone (lanes 3 and 4). Lane 5 shows COX-2 expression in untreated day 3 granulation tissue. 
dexamethasone (a glucocorticoid) in a dose-dependent manner. Both celecoxib and dexamethasone were equi-effective in inhibiting fluid accumulation and both these drugs significantly brought down the protein concentration of the exudate. The antiinflammatory effect of celecoxib and dexamethasone has been attributed to the inhibition of PG synthesis. ${ }^{18,19}$ In our study celecoxib produced an $80 \%$ decrease in $\mathrm{PGE}_{2}$ levels in the exudate while $\mathrm{PGE}_{2}$ was undetectable in the dexamethasone-treated group. Both, celecoxib and dexamethasone significantly inhibited leucocyte influx into the pouch; however, dexamethasone was more potent in this regard. The COX-2 inhibitor celecoxib inhibits only PG synthesis, while dexamethasone also regulates the expression of several cytokines, adhesion molecules and inducible nitric oxide synthase in addition to COX-2. ${ }^{18}$ The pronounced inhibitory effect of dexamethasone on leucocyte influx has also been attributed to its ability to inhibit leucocyte migration as well as to facilitate the loss of PMN leucocytes from the exudate. ${ }^{20}$ Both celecoxib and dexamethasone significantly increased the monocyte count as compared with the control group, possibly by inhibiting $\mathrm{PGE}_{2}$ synthesis. ${ }^{21}$ It is also possible that both drugs augment 5-lipoxygenase pathway in monocytes and thus stimulate monocyte chemotaxis. ${ }^{22,23}$

We further studied the effect of DL on COX-2 expression in granulation tissue. COX-2 expression was induced by DL in a time-dependent manner with maximum expression occurring on day 5 , as also seen in carrageenin-induced granulation. ${ }^{19}$ Initially, the granulation of the tissue progressed with an increase in COX-2 expression but, subsequently, the COX-2 expression continued even though the granulation has started regressing. COX 2 may be proinflammatory during the early phase of inflammation but may aid resolution at the later stage by generating an alternative set of anti-inflammatory prostaglandins. ${ }^{24}$ In our study, both celecoxib and dexamethasone completely inhibited tissue granulation as well as COX-2 expression.

Thus, our study shows that the inflammatory response elicited by latex of Calotropis procera involves early cellular infiltration accompanied by the release of $\mathrm{PGE}_{2}$ and subsequent formation of granulation tissue associated with COX-2 induction.

\section{References}

1. Tomar VPS, Agarwal PK, Agarwal BL. Toxic iridocyclitis caused by Calotropis. J All India Ophthal Soc 1970; 18: 15-16.
2. Handa F, Sadana JK, Sharma PK. Allergic contact dermatitis due to plant of Calotropis procera (Vern. Ak.) A case report. Ind J Dermatol 1984; 29: $27-29$.

3. Shivkar YM, Kumar VL. Histamine mediates the proinflammatory effect of latex of Calotropis procera in rats. Mediat Inflamm 2003; 12: 299302.

4. Singh H, Kumar S, Dewan S, Kumar VL. Inflammation induced by latex of Calotropis procera - a new model to evaluate anti-inflammatory drugs. J Pharmacol Toxicol Methods 2000; 43: 219-224.

5. Shivkar YM, Kumar VL. Effect of anti-inflammatory drugs on pleurisy induced by latex of Calotropis procera in rats. Pharmacol Res 2004.

6. O'Neill GP, Ford-Hutchinson AW. Expression of mRNA for cyclooxygenase-1 and cyclo-oxygenase-2 in human tissues. FEBS Lett 1993; 330: $156-160$.

7. Vane JR, Mitchell JA, Appleton I, Tomlinson A, Bishop-Bailey D, Croxtall $\mathrm{J}$, Willoughby DA. Inducible isoforms of cyclo-oxygenase and nitricoxide synthase in inflammation. Proc Natl Acad Sci USA 1994; 91: 2046-2050.

8. Sedgwick AD, Koh MS, Willoughby DA, Pelletier M. Effects of sera and exudate from carrageenan-treated rats on two models of acute inflammation. Agents Actions 1981; 11: 477-481.

9. Seibert K, Zhang Y, Leahy K, et al. Pharmacological and biochemical demonstration of the role of cyclo-oxygenase 2 in inflammation and pain. Proc Natl Acad Sci USA 1994; 91: 12013-12017.

10. Edwards JC, Sedgwick AD, Willoughby DA. The formation of a structure with the features of synovial lining by subcutaneous injection of air: an in vivo tissue culture system. J Pathol 1981; 134: 147-156.

11. Bradford MM. A rapid and sensitive method for the quantitation of microgram quantities of protein utilizing the principle of protein-dye binding. Anal Biochem 1976; 72: 248-254.

12. Chomczynski P, Sacchi N. Single-step method of RNA isolation by acid guanidinium thiocyanate-phenol-chloroform extraction. Anal Biochem 1987; 162: 156-159.

13. Dubois RN, Tsujii M, Bishop P, Awad JA, Makita KA, Lanahan A. Cloning and characterization of a growth factor-inducible cyclo-oxygenase gene from rat intestinal epithelial cells. Am J Physiol 1994; 266: 822-827.

14. Tack I, Castano EM, Pecher C, et al . Endothelin increases NO-dependent cGMP production in isolated glomeruli but not in mesangial cells. Am J Physiol 1997; 272: F31-F39.

15. Form DM, Auerbach R. PGE 2 and angiogenesis. Prog Soc Exp Biol Med 1983; 172: $214-218$

16. Yamashita T, Ishibashi Y, Nagaoka I, Kasuya K, Masuda K, Warabi H, Shiokawa Y. Studies of glycogen-induced inflammation of mice. Dynamics of inflammatory responses and influence of antiinflammatory drugs and protease inhibitors. Inflammation 1982; 6: 87-101.

17. Willis D, Moore A, Frederick R, Willoughby DA. Heme oxygenase: a novel target for the modulation of the inflammatory response. Nat Med 1996; 2: $87-90$.

18. Pinheiro RM, Calixto JB. Effect of the selective COX-2 inhibitors, celecoxib and rofecoxib in rat acute models of inflammation. Inflamm Res 2002; 51: 603-610

19. Ghosh AK, Hirasawa N, Niki H, Ohuchi K. Cyclo-oxygenase-2 mediated angiogenesis in carrageenin-induced granulation tissue in rats. $J$ Pharmacol Exp Ther 2000; 295: 802-809.

20. Miyasaka K, Mikami T. Comparison of the anti-inflammatory effects of dexamethasone, indomethacin and $\mathrm{BW} 755 \mathrm{C}$ on carrageenin-induced pleurisy in rats. Eur J Pharmacol 1982; 77: 229-236.

21. Zeidler R, Csanady M, Gires O, Lang S, Schmitt B, Wollenberg B. Tumor cell-derived prostaglandin E2 inhibits monocyte function by interfering with CCR5 and Mac-1. FASEB J 2000; 14: 661-668.

22. Uz T, Dwivedi Y, Savani PD, Impagnatiello F, Pandey G, Manev H Glucocorticoids stimulate inflammatory 5-lipoxygenase gene expression and protein translocation in the brain. J Neurochem 1999; 73: 693-699.

23. Colli S, Caruso D, Tremoli E, Stragliotto E, Morrazoni G, Galli G. Effect of single oral administration of nonsteroidal anti-inflammatory drugs to healthy volunteers arachidonic acid metabolism in peripheral polymorphonuclear and mononuclear leukocytes. Prostaglandins Leukot Essent Fatty Acids 1988; 34: 167-174.

24. Gilroy DW, Colville-Nash PR, Willis D, Chivers J, Paul-Clark MJ, Willoughby DA. Inducible cyclooxygenase may have anti-inflammatory properties. Nat Med 1999; 5: 698-701.

\section{Received 9 February 2004 Accepted 12 March 2004}




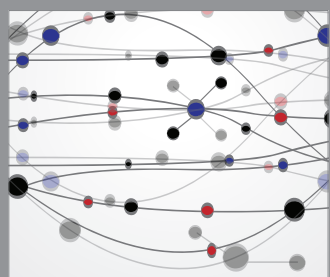

The Scientific World Journal
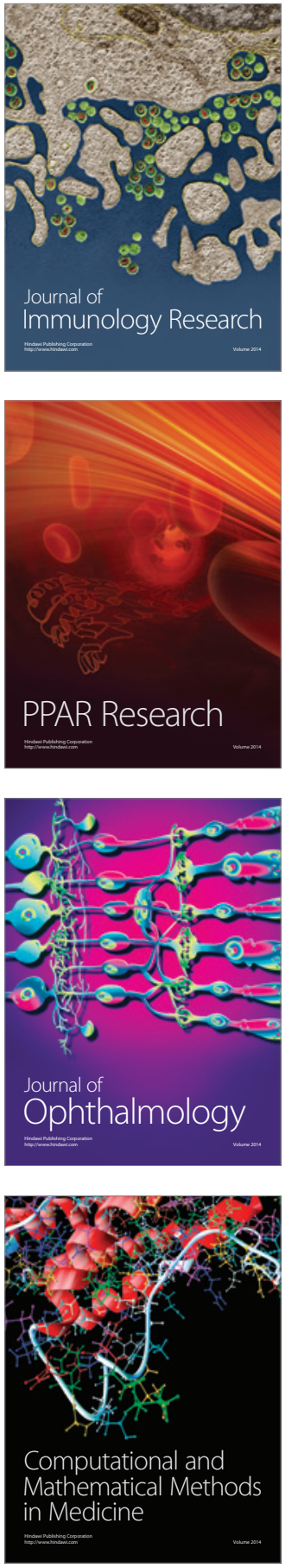

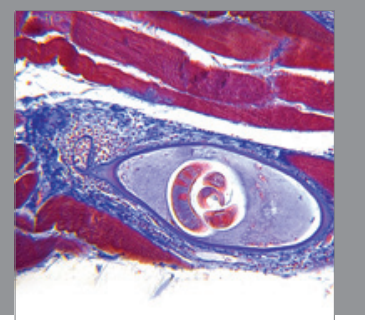

Gastroenterology

Research and Practice
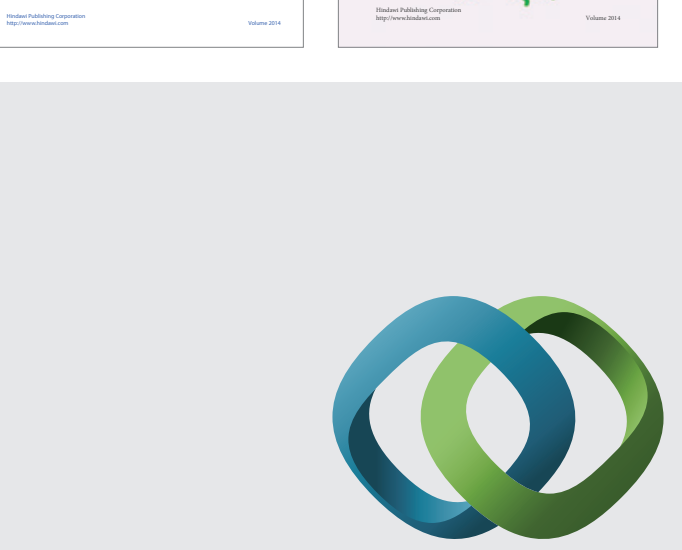

\section{Hindawi}

Submit your manuscripts at

http://www.hindawi.com
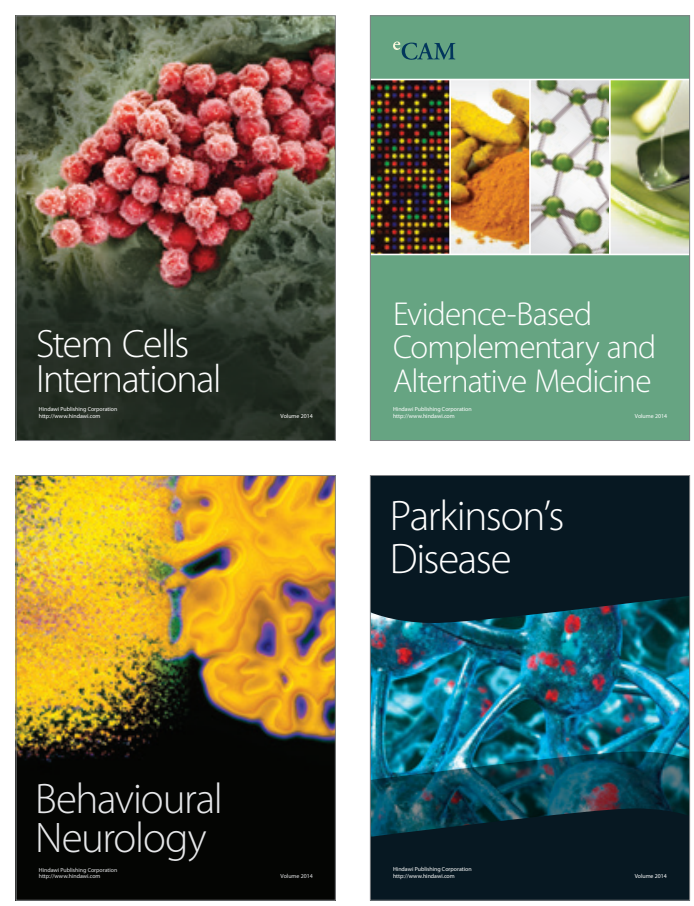

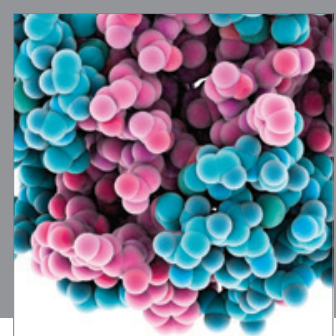

Journal of
Diabetes Research

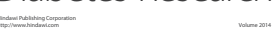

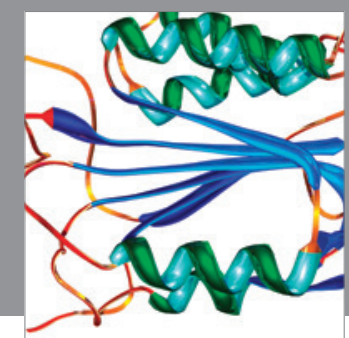

Disease Markers
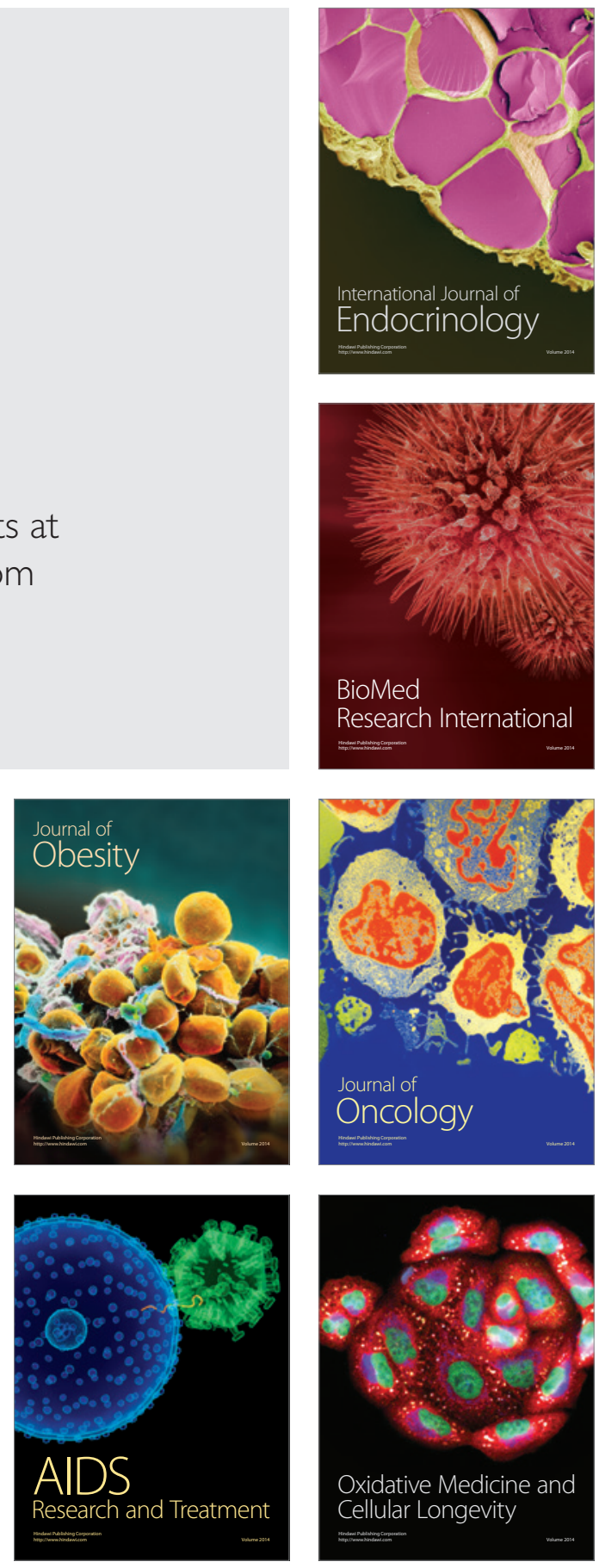